\title{
THE PROCEDURE IN LITIGATIONS FOR PROTECTION AGAINST DOMESTIC VIOLENCE
}

\author{
Vladimir Boranijašević*
}

\begin{abstract}
Domestic violence represents a phenomenon that has justifiably been dedicated large attention to lately. If in a family appears any kind of physical, sexual, economical or psychological abuse of one member by the other, it undoubtedly results in violation of safety and the relationship of trust between the members of family and leads to serious violation of the very institution of the family. Domestic violence is a subject of regulation of a large number of international and domestic legal acts. In the Republic of Serbia, regulations of the Family Law prescribe the rules to act in accordance with in a special kind of legal proceedings for protection against domestic violence. In the paper the author points to specificities of the procedure in litigations for protection against domestic violence, points to the process principles it is based on and to the exceptions from the rules of the general legal procedure. The author notes the theoretical opinions and jurisprudence opinions regarding certain issues about this procedure and analyses certain legal solutions in the legislations of the countries in the region in the field of protection against domestic violence.
\end{abstract}

INTRODUCTION.......................................................................... 444

I. DOMESTIC VIOLENCE IN LEGAL DOCUMENTS.....................................446

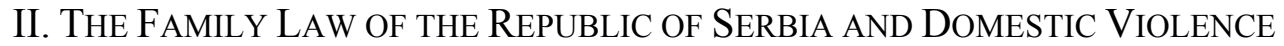

III. MeAsures of Protection Against Domestic Violence 450

IV. The Procedure In Litigations FOR PROTECTION AGAINST DOMESTIC

VIOLENCE 452

CONCLUSION 458

\section{INTRODUCTION}

As already known, the family represents a basic cell of society. A healthy family, a healthy society, we could conclude. Ever since the beginnings of the family as an institution, it has been denoted as a calm harborage where its members satisfy their needs, where they are surrounded by love and understanding and which offers them security. A family has a raising and educational function, protection and psychological function. In a family psychological needs are satisfied, various ways of help and

\footnotetext{
* Associate Professor, Faculty of Law, University of Priština with Temporary Head Office in Kosovska Mitrovica, the Republic of Serbia. Research fields: Civil Process Law, Arbitration Law, Executive Proceedings.
} 
protection are offered to its members, and it also has a role of a significant factor in the process of socialization. A family is comprised of permanent and versatile relations of its members. All of these functions are realized in a family when there are good relations in it, when inequality of any kind is not present in it and when no kind of violence is present in the family. This certainly does not mean that in the modern era there are no changes which affect the family as an institution. Quite contrary; changes happen and they affect the living conditions of a large number of families, the quality of their lives, the contents of family functions and their execution. ${ }^{1}$ However, this does not mean that the family loses its functions and that it does not continue to be a significant community for both the individual and society. When violence appears in family, it cannot function smoothly and family relations are deranged.

Violence in family represents a phenomenon that large attention has been devoted to lately; and justifiably. If in the family there appears any kind of physical, sexual, economical or psychological abuse of one member by the other, it undoubtedly results in violation of safety and a relationship of trust between the members of the family and this also leads to serious violation of the very institution of the family. ${ }^{2}$ Domestic violence is a universal phenomenon; it represents a model of behavior, ${ }^{3}$ it is affected by social violence, it significantly affects the mental health of those who are directly exposed to it and contributes to resorting to violence in interpersonal relations of those people who have experienced violence. ${ }^{4}$ Also frustrations, fear and uncertainty that certain members of a family experience in the society and they transfer it to their family could be reasons for a high level of violence in the family. The most common way of

\footnotetext{
${ }^{1}$ D. Vilić, Porodica u kontekstu savremenih društvenih promjena (The Family in the Context of Contemporary Social Changes), 1(2) Sociološki diskurs (Sociological Discourse) 34 (December 2011).

${ }^{2}$ N. Petrušić, Porodičnopravna zaštita od nasilja u porodici u pravu Republike Srbije (Family Legal Protection against Domestic Violence in the Legal System of the Republic of Serbia), Collection of papers "Novo porodično zakonodavstvo" (The New Family Legislation), Pravni fakultet u Kragujevcu - Centar za porodično pravo, Kragujevac 21 (2006).

3 "Domestic violence represents a model of behavior, that one member of the family takes, i.e. manifests towards the other, in order to establish power and control or satisfy some of their needs at the expense of another family member, and not an isolated incident" (Presuda Apelacionog suda $u$ Novom Sadu (The Judgement of the Appellate Court), No. Gž2. 51/10 on 03/02/2010, Bilten Apelacionog suda u Novom Sadu, No. 1/2010, at 95).

${ }^{4}$ N. Petrušić, Krivičnopravna i porodičnopravna zaštita od nasilja u porodici (Criminal and Family Legal Protection against Domestic Violence), Bilten sudske prakse Vrhovnog suda Srbije, No. 2/2008, Beograd, at 565-566.
} 
domestic violence is violence of a man over a woman ${ }^{5}$. However, violence over children and parents is the kind of violence becoming more and more intensive.

The National Strategy for Gender Equality of the Republic of Serbia for the Period from 2015 to 2020 with the Action Plan from 2016 to 2018 contains alarming data about the large presence of domestic violence and violence in partnership relationships. More accurately, it is noted that girls and women are still often exposed to serious forms of violence as violence in family and partnership relations, sexual harassment, rape and persecution. The data show that every second woman in the Republic of Serbia has experienced some form of physical violence (46.1\%), while every third woman has experienced a physical assault from a member of the family $(30.6 \%)$, and that the most common assaulters are either partners or husbands of the victim. The most common form of violence in family and partnership relations is psychological violence, then physical and economic violence. One third of all women have experienced one form or a combination of different forms of violence. The most serious cases of physical violence over women have been performed by men $(96 \%)$. In the year of 2013 , men $(1,451$ of them) have been $95 \%$ of all the convicted adult persons for the criminal act of performing family violence (p. 24). ${ }^{6}$

\section{DOMESTiC Violence IN Legal DoCumentS}

Domestic violence is the subject of regulation of a large number of international and national legal documents. Starting with the Universal Declaration of the UN on Human Rights in 1948, the Convention on Children's Rights in 1989, Recommendation No. R (90) 2 of the Committee of Ministers of the European Council on Social Measures Concerning Domestic Violence, Beijing Declaration and Platform for Action in 1995, accepted at the Fourth World's Conference on Women in Beijing on December 15, 1995, Recommendation 1,450 (2000) of the Parliamentary Assembly of the European Council on Violence over Women in Europe, Recommendation 1,582 (2002) of the Parliamentary Assembly of the European Council on Domestic Violence over Women, Recommendation Rec (2002) 5 of the Committee of Ministers of the European Council on

\footnotetext{
${ }^{5}$ A large number of women homicides have happened in the Republic of Serbia in 2015. As many as 34 women were murdered as a result of domestic-partner violence. See Redovan Izvestaj Poverenika za zastitu ravnopravnosti za 2015. godinu (Regular Report of the Commissioner for Protection of Equality for 2015), at 57-58. Available at www.ravnopravnost.gov.rs/rs/извештаји/извештаји. ${ }^{6}$ Available at http://www.mgsi.gov.rs/lat/dokumenti/nacionalna-strategija-za-rodnu-ravnopravnostza-period-od-2016-do-2020-godine-sa-akcionim.
} 
Protection of Women against Violence, through the Recommendation 1,905 (2010) of the Parliamentary Assembly of the European Council, accepted in March 2010 which points to the necessity of protection of children who have witnessed domestic violence, to the Convention of the European Council on Prevention and Fighting against Violence over Women and Domestic Violence, created in Istanbul on May 11, 2011 and put into effect on August 1, 2014, ${ }^{7}$ domestic violence is defined as illicit behavior which violates human rights, and the very documents prescribe and establish mechanisms for prevention of domestic violence.

In the legislation of the Republic of Serbia, as well, there are a large number of documents forbidding domestic violence. The Constitution of the Republic of Serbia ${ }^{8}$ states that the state guarantees equality of women and men, forbids direct and indirect discrimination on any ground, especially on the grounds of sex, it guarantees legal protection of human and minority rights guaranteed by the Constitution, guarantees inviolability of physical and psychological integrity, guarantees protection of children against psychological, physical economic and any other form of exploitation or abuse and guarantees a special protection of families, mothers, single parents and children.

In the Republic of Serbia, ${ }^{9}$ domestic violence has been a criminal act since 2002. Defining the rules about the criminal act of domestic violence was the first step in incrimination of this kind of behavior which is unacceptable and undesirable in the modern world. The criminal act of domestic violence has been defined by the regulations from the article 194 of the Criminal Law of the Republic of Serbia, ${ }^{10}$ in the chapter nineteen which is devoted to criminal acts against marriage and family. The legislator first informs us about the contents of the criminal act of domestic violence,

\footnotetext{
${ }^{7}$ Zakon o potvrđivanju Konvencije Saveta Evrope o sprečavanju i borbi protiv nasilja nad ženama i nasilja u porodici (The Law on Ratification of the Convention of the European Council on Prevention and Fighting against Violence over Women and Domestic Violence) was introduced on October 31, 2013 ("Službeni glasnik RS-Međunarodni ugovori”, No. 12/2013), while in "Službeni glasnik RSMeđunarodni ugovori", No. 4/2014, it was proclaimed that the Convention comes into effect on August 1, 2014.

${ }^{8}$ See "Službeni glasnik RS", No. 98/2006.

${ }^{9}$ In the Republic of Serbia, the National Strategy for Prevention and Suppression of Domestic Violence over Women and Violence over Women in Partnership Relations was introduced in 2011 ("Službeni glasnik RS", No. 27/2011), which has defined the strategic goals: establishing the system of primary, secondary and tertiary prevention; upgrading of the normative framework for protection of women against violence, upgrading of multisectoral cooperation and building of capacities of organs and services and upgrading of the system of measures for protection and support of victims of violence.

${ }^{10}$ See "Službeni glasnik RS”, No. 85/2005, 88/2005, 107/2005, 72/2009, 111/2009, 121/2012, 104/2013, 108/2014.
} 
and then prescribes modalities of punishment depending on the form which the domestic violence has been performed in, as well as towards whom it has been performed and with which consequences. ${ }^{11}$ In general, the person who, using violence, threat to attack the life or body or rude or arrogant behavior, endangers the tranquility, body integrity or mental condition of a member of their family, will be punished by imprisonment of three months to three years. If domestic violence defined this way is performed by using dangerous tools, weapons or other object which can severely damage health or hurt a body, or if the domestic violence leads to a serious body injury or health impairment, or the domestic violence act has been performed on an underage, the prescribed penalties are stricter. ${ }^{12}$

\section{The FAmily Law of the Republic of Serbia and Domestic Violence}

A huge step in recognition of domestic violence as a significant social problem as well as the need for providing protection to persons exposed to domestic violence was made by the act of regulating domestic violence by the regulations of the Family Law of the Republic of Serbia. ${ }^{13}$ The law contains both material legal and process legal regulations concerning the protection against domestic violence. Firstly, the law states that domestic violence is forbidden and that according to the law everyone has the right to protection against domestic violence. ${ }^{14}$

According to the law, domestic violence is a kind of behavior by which one member of a family endangers body integrity, mental health or tranquility of another member of the family (article 197, paragraph 1). It is considered that this widely stated definition of domestic violence was necessary so that protection would comprise all the acts of domestic violence, and that defining the contents of violent behavior is left to the judicial practice. ${ }^{15}$ Also, domestic violence as a social phenomenon is

\footnotetext{
${ }^{11}$ More on criminal legal protection against domestic violence, in: I. Josifović, Krivično delo nasilje $u$ porodici u praksi (The Criminal Act of Domestic Violence in Practice), Bilten Apelacionog suda $\mathrm{u}$ Novom Sadu, No. 6/2014, at 147-174.

${ }^{12}$ The penalties are between six months and fifteen years of imprisonment. The person who has performed the act of domestic violence which has resulted in a death of a family member will receive a penalty of three to fifteen years of imprisonment. More on the statistical data about the persons convicted for the criminal act of domestic violence, in: V. Nikolić-Ristanović, Praćenje primene zakonskih rešenja o nasilju u porodici u Srbiji: nalazi pilot istraživanja (Monitoring the Implementation of Legal Decisions on Domestic Violence in Serbia: The Results of a Pilot Survey), UN WOMEN 4-5 (2013).

${ }^{13}$ See "Službeni glasnik RS", No. 18/2005, 72/2011, 6/2015. Hereinafter FL RS.

${ }^{14}$ Article 10, paragraph 1 and paragraph 2 of the FL RS.

${ }^{15}$ M. Draškić, Nasilje u porodici: prva presuda Vrhovnog suda Srbije (Domestic Violence: the First Verdict of the Supreme Court of Serbia), Anali Pravnog fakulteta u Beogradu, LVI, No. 2/2008, at 346.
} 
considered to be characterized by gradualism and continuity of expression, so that defining domestic violence this way enables protection against domestic violence in the early stages as well as in the stages of taking the worst forms. ${ }^{16}$ This general way of defining represents a legal standard, so the legislator has explicitly regulated what kind of behavior is especially considered to be domestic violence. Therefore domestic violence is especially considered to be: The inflicting or attempt of inflicting a body injury, causing fear by a threat to kill or inflict a body injury to a member of the family or a person close to them; A forced sexual intercourse; Incitement to a sexual intercourse or a sexual intercourse with a person under the age of 14 or a disabled person; Restriction of movement or communication with third parties; Insulting or any other impudent, arrogant and malicious conduct. ${ }^{17}$ Also the words "impudent", "arrogant" and "malicious" conduct also represent a legal standard and it is up to the assessment of the court whether a certain action will be assessed as impudent, arrogant and malicious conduct. ${ }^{18}$ More accurately, impudence, arrogance and maliciousness are characteristics of domestic violence and the contents of these legal standards can be defined only in regard to general social norms and values. ${ }^{19}$

A very significant fact is that the law defines who the members of a family are concerning domestic violence. They are spouses or former spouses; Children, parents and other blood relatives, or people in law or adoptive relationships, or people related by foster care; People who live or who used to live in the same family household, unmarried couples or former unmarried couples; People who used to be or still are in a mutual emotional or sexual relationship, or have a child or a child is about to be born, although they have never lived in the same family household. ${ }^{20}$ It is evident that the legislator considers members of a family to be not only the members forming a family as a bio-psycho-social community of parents and their

\footnotetext{
${ }^{16}$ M. Milikić, Porodičnopravna zaštita od nasilja u porodici u parničnom postupku (Family Legal Protection against Domestic Violence in Legal Proceedings), Bilten Vrhovnog kasacionog suda, No. 3/2011, at 189 .

${ }^{17}$ Article 197, paragraph 2 of the FL RS. About protection measures, and M. Wagner, Putokaz za moja prava u zaštiti od nasilja u porodici (A Milestone for My Rights in Protection against Domestic Violence), Autonomni ženski centar 32-35 (Beograd 2005).

18 "While assessing whether some kind of conduct of a member of a family towards another member of the family, caused by their mutual disagreements, represents domestic violence, it is relevant whether that conduct has a character and intensity to endanger body integrity, mental health or tranquility of the other member of the family" (Presuda Apelacionog suda u Novom Sadu (The Verdict of the Appellate Court in Novi Sad), Gž2 99/11 on 21/02/2012, Bilten Apelacionog suda u Novom Sadu, No. 4/2012, at 126)).

${ }^{19}$ N. Petrušić 579 (2008).

${ }^{20}$ Article 197, paragraph 3, point $1-5$ of the FL RS.
} 
born or adopted children, but also former spouses, former unmarried couples, people related by law relationships, people in foster relations, as well as people in emotional or sexual relationships who do not live, nor have they lived, in a family household. It is indisputable that the definition of family members is very wide, and that it is done this way on one hand in order to prevent violence among the members of an existing as well as a former marriage or unmarried relationship, among people in adoptive and law relationships and people in foster relationship, but also the people who do not live in a family household but are connected by an emotional or sexual relationship or they have a child or are waiting for one to be born. On the other hand, imposition of any kind of measures of protection against domestic violence on any of these persons also has a strong preventive function, in the way that it is shown to other members of society that they can be sanctioned if they do not behave according to the determined social standards of conduct in a family, unmarried community or other kind of family community.

\section{MeAsures of Protection against Domestic Violence}

The regulations of the FL RS precisely determine the protective measures which can be imposed in a special legal procedure in case of domestic violence. The purpose of imposing protective measures is limitation of maintaining personal relationships with the other member of a family or a temporary prohibition of maintaining a relationship. The court can determine one or more measures of protection against domestic violence against the person conducting domestic violence. According to the regulation from the article 198, paragraph 2, of the FL RS, the measures of protection against domestic violence are: Issuing an order for eviction from a family apartment or house, regardless the ownership or real estate leasing; Issuing an order for moving into a family apartment or house, regardless the ownership or real estate leasing; A restraining order to a member of a family to a certain distance; A restraining order to the area of around the place of living or working of a family member and the prohibition of further harassment of a family member. ${ }^{21}$

A measure of protection against domestic violence can last for a year at the most. However, it can be prolonged for as long as the reasons for which

\footnotetext{
${ }^{21}$ Regulations of the Preliminary Draft of the Civil Code of the Republic of Serbia, the regulation from the Article 2452, paragraph 2, point 5 prescribes mandatory treatment of alcoholism, drug addiction and other kinds of addiction as a measure of protection against domestic violence (available at http://www.propisi.com/assets/files/gradjanski_zakonik_RS-prednacrt.pdf).
} 
it has been imposed persist. ${ }^{22}$

The imposed measure of protection against domestic violence ends by termination of the period it has been imposed to, but it can also end before termination of the period if the reasons it has been imposed for fail to exist. $^{23}$

When it comes to protective measures, the situation in legal systems in the region is different. In the Republic of Srpska the Law on Protection against Domestic Violence is Active ${ }^{24}$, and the regulation from the article 2, paragraph 2 states that the procedure of protection against domestic violence is provided in the Misdemeanor Proceedings, by applying the regulations of the Law on Offences. ${ }^{25}$ In the Misdemeanor Proceedings the court can impose misdemeanor sanctions in the form of protective measures, ${ }^{26}$ which are: A removal from an apartment, house or some other kind of living space; Restraining order to the victim of violence, providing protection to the victim of violence; Prohibition of harassment or spying on the victim of violence; The obligation of psychosocial treatment; Mandatory addiction treatment and working for a humanitarian organization or local community. Duration has been determined for each of the prescribed measures. ${ }^{27}$

The Law on Protection against Domestic Violence of the Republic of Montenegro ${ }^{28}$ after defining domestic violence (article 3) has defined forms of violence and determined protective measures that are imposed in case of domestic violence. The legislator very thoroughly defines forms of violence from two aspects. First of all taxatively are mentioned forms of behavior which are considered to be jeopardizing of the physical, psychological, sexual or economic integrity, mental health and tranquility of the other member of the family, and then also the forms of behavior when a member

\footnotetext{
${ }^{22}$ If the violence persists, the prosecutor has a possibility to submit a lawsuit to ask the court for continuation of the imposed measure, and then they start the procedure for continuation of the measure of protection against domestic violence. The prosecutor has to submit a lawsuit before termination of the imposed measure. It certainly does not prevent the prosecutor from requesting providing legal protection which can be a renewed imposing of the already imposed measure in the previous procedure, after the termination of the imposed measure, in a new special legal procedure. ${ }^{23}$ Article 200 of the FL RS.

24 “Službeni glasnik Republike Srpske”, No. 118/2005. Hereinafter LPDV RSP.

${ }^{25}$ In the Republic of Srpska, domestic violence is also the subject of criminal legal protection. See I. Marković, Pravna zaštita žrtava nasilja u porodici u Republici Srpskoj (Legal Protection of Victims of Domestic Violence in the Republic of Srpska), Temida, No. 1/2008, at 6-9.

${ }^{26}$ More on protective measures and legislative acts which regulate their implementation, in I. Marković 15-20 (2008).

${ }^{27}$ On contents and duration of the measures, see Atricle 11, paragraph 3; Article 12, paragraph 3; Article 14, paragraph 2; Article 15, paragraph 1 and 2 and Article 16, paragraph 1 and 2 of the LPDV RSP.

28 “Službeni list Crne Gore”, No. 46/2010. Hereinafter LPDV RM.
} 
of a family does not take enough care of a child or member of the family they are obliged to take care of. ${ }^{29}$ In terms of protective measures, one or more protective measures can be imposed on the person who has conducted the act of violence. They are: A removal from the apartment or other living space; Restraining order; Prohibition of harassment and spying; Mandatory addiction treatment; Mandatory psychosocial treatment. For each protective measure conditions under which it can be imposed have been defined as well as the time interval. ${ }^{30}$

Regulations of the Law on Protection of Domestic Violence of the Republic of Croatia ${ }^{31}$ define that, besides the protective measures defined by the Misdemeanor Proceedings, the court can also impose the following protective measures on the executor of violence: Mandatory psychosocial treatment; Restraining order to the victim of domestic violence; Protection of harassment or spying of the person exposed to violence; Removal from the apartment, house or any other living space; Mandatory addiction treatment and taking away of the object which has been used or planned to be used in committing an offence. ${ }^{32}$ The measures are imposed ex officio or on request of the person exposed to violence.

In the Republic of Slovenia in 2008 the Law on Prohibition of Domestic Violence was introduced. ${ }^{33}$ According to the law, the following protective measures can be imposed on the executor of violence: Prohibition of entering the apartment in which the victim lives; Prohibition of retention in certain vicinity of the place of living of the victim; Prohibition of retention and approaching to the place where the victim is regularly situated (workplace, school, nursery); Prohibition of making contact with the victim of violence in the family in any way, including the means of distance communication; Prohibition of making any kind of contact with the victim of violence. ${ }^{34}$ The court imposes the mentioned measures in duration of six months, while the victim of domestic violence can require the continuation of those measures for additional six months.

\section{The Procedure In Litigations for Protection against DomestiC VIOLENCE}

The process legal regulations of the FL RS define the rules according

\footnotetext{
${ }^{29}$ Article 8 of the LPDV RM.

${ }^{30}$ Article $21-25$ of the LPDV RM.

31 "Narodne novine", No. 137/09, 14/10, 60/10. Hereinafter LPDV RC.

${ }^{32}$ Article 11, paragraph 2 of the LPDV RC.

33 "Uradni List Republike Slovenije", No. 16/2008. Hereinafter LPDV RSL.

${ }^{34}$ Article 19, paragraph 1, point $1-5$ of the LPDV RSL.
} 
to which to act in litigations for protection against domestic violence. According to its legal nature the procedure in litigations for protection against domestic violence is a special litigation procedure in which to act according to the rules defined by regulations of the FL RS but with application of regulations of the Law on Civil Procedure of the Republic of Serbia. ${ }^{35}$ In the literature of procedural law there are certain opinions that when it comes to this procedure it is not a special kind of procedure, but a contentious procedure in which the court, by imposing a certain protective measure, offers protective help to the victim of domestic violence, and in which, with joint action with the court, relations of different parties are arranged. ${ }^{36}$

The procedure in litigations for protection against domestic violence is initiated as an independent procedure. This procedure can also be conducted as a joint procedure which is conducted together with a procedure in conjugal litigations, maternity and paternity litigations, litigations for protection of children's rights, litigations for deprivation and restoring of parental rights and litigations for exercising parental rights.

In the procedure in litigations for protection against domestic violence Magistrate court is in charge ${ }^{37}$ and the issue of territorial jurisdiction is regulated in a specific way. Generally territorially competent court for the procedure in litigations for protection against domestic violence is the court according to the permanent or temporary residence of the respondent, in this case the person conducting domestic violence. In order to alleviate the position of the person who is or has been the subject of domestic violence, the law regulates that apart from the court of general territorial jurisdiction, the court on the territory of which the member of the family who has been the subject of violence has a permanent or temporary residence is also in charge. ${ }^{38}$

The procedure in litigations for protection against domestic violence is initiated by bringing charges. There are two types of charges: One which initiates the procedure for protection against domestic violence, and the other which initiates the procedure for continuation of a measure for protection against domestic violence in cases when there is a need for its

\footnotetext{
35 "Službeni glasnik RS", No. 72/2011, 49/2013-Regulation US, 74/2013-Regulation US and 55/2014 of the FL RS defines in the Article 202 that in the procedure of the court which is related to family relations, regulations of the law that regulates civil procedure are applied, if not defined differently by the law.

${ }^{36}$ G. Stanković, Građansko procesno pravo, prva sveska, Parnično procesno pravo (Civil Process Law, volume I, Litigation Process Law), Megatrend Univerzitet 605 (Beograd 2013).

${ }^{37}$ Article 22 of the Law on Regulation of Courts, "Službeni glasnik RS”, No. 116/2008, 104/2009, 101/2010, 31/2011, 78/2011, 101/2011 and 101/2013, 106/2015, 40/2015, 13/2016.

${ }^{38}$ Article 283 of the FL RS.
} 
continuation. ${ }^{39}$ There are also charges for cessation of the measure of protection against domestic violence which is brought with a goal of a certain measure of protection to be terminated before the duration of the measure is over.

The legal nature of the charges in the procedure in litigations for protection against domestic violence is specific. Charges are simultaneously of both constitutive and condemnatory nature. In cases the court is required to impose a measure of protection against domestic violence and order the respondent to do something, endure or refrain from doing something, the charges are of condemnatory character. On the other hand, the charges ask for a person to be deprived of some right or conduct, so the charges are also of constitutive character. ${ }^{40}$ Charges can be of constitutive character only in those situations when the prosecutor demands for a certain protective measure to cease.

Process legitimation for bringing charges belongs to the member of a family who has been the subject of violence, legal representative of that person, public attorney and guardianship authority. ${ }^{41}$ All of these parties can bring charges and initiate the procedure in litigations for protection against domestic violence with the aim of the court to impose one or more measures of protection against domestic violence. The process legitimation for bringing charges for termination of protective measures has the person against whom the measure has been determined. A child also has the active process legitimation for initiating the procedure. However, it is necessary for the child as a party in the procedure in such case to be represented by a legal representative. If there is, however, a conflict of interest between the child and the legal representative, the child is allocated a temporary representative. ${ }^{42}$

\footnotetext{
39 "When the duration of the measure for protection against domestic violence is over, further action of the court which has brought a decision in the legally ended litigation procedure cannot be required, but a new enforcement document for returning to co-ownership of the apartment has to be received in a special litigation procedure" (The decision of the District Court in Novi Sad, Gž. 676/2008 on 20/02/2008 and the decision of the Supreme Court of Serbia in Belgrade, Rev. 2364/2008 on 17/09/2008, Bilten sudske prakse Okružnog suda u Novom Sadu, No. 14/2008, Intermex, Beograd). ${ }^{40}$ More on this in: G. Stanković 606 (2013); N. Petrušić 40 (2006).

${ }^{41}$ Article 284, paragraph 2 of the FL RS. In case the guardianship authority has not initiated the procedure in litigations for protection against domestic violence, the court can require the guardianship authority to provide help in collecting the necessary evidence and also give their opinion about the expediency of the measure of protection against domestic violence that has been required. In that case the guardianship authority has a role of an auxiliary authority of the court or specific expert (More on this in: G. Stanković 606 (2013); M. Draškić 351 (2008); N. Petrušić 41 (2006)). ${ }^{42} \mathrm{~A}$ child can alone or by means of another person or institution require allocation of a temporary representative when there are opposite interests between them and their legal representative. A child can require this if they are older than 10 and they are capable of judgment (Article 265, paragraph 3 of the FL RS).
} 
The civil court has a possibility to initiate the procedure for protection against domestic violence ex officio. The court will ex officio initiate the procedure for protection against domestic violence as an adhesion procedure which is conducted associated with the basic procedure. More accurately, when a person with process legitimation has not initiated the procedure for protection against domestic violence and has not required imposing of a certain protective measure, and the court in the procedure conducted on the basis of reconnaissance comes to the finding that there is a need for providing protection against domestic violence, the court will ex officio initiate a procedure for imposing a measure of protection against domestic violence.

The basic process principles that this special civil procedure is based on have significantly been changed as compared to the process principles that the general civil procedure is based on. The opinion of Prof. Stanković has to be agreed on, when she says that "concretization of the process principles in the same manner as in the general civil procedure would represent an obstacle for realization of the principles on which material family law is based, realization of public interest and protection of family rights of individuals". ${ }^{43}$ On the other hand, the very nature of family relations is specific and, as such, requires modification of the principles according to which to act in the procedure for offering legal protection.

Although urgency in acting is proclaimed by general regulations related to acts in the area of family legal relations, ${ }^{44}$ the procedure in litigations for protection against domestic violence is, according to the legislator, especially urgent (Article 285, paragraph 1 of the FL RS). This rule is concretized by individual decisions. Namely, the court is obliged to schedule the first hearing to be held within eight days from the day of receiving the charges in court. Also, the second instance court is obliged to bring a decision within 15 days from the day when the first instance court delivered a complaint with all the other necessary documents.

The principle of urgency is also concretized by the rule according to which the charges are not delivered to the respondent for a response. This is

\footnotetext{
${ }^{43} \mathrm{G}$. Stanković, Osnovna načela posebnih parničnih postupaka u porodičnim stvarima (The Basic Principles of Special Civil Procedures in Family Matters), Collection of papers "Novo porodično zakonodavstvo" ("The New Family Legislation”), Pravni fakultet u Kragujevcu-Centar za porodično pravo, Kragujevac 484 (2006).

${ }^{44}$ The procedure related to family relations is urgent if it is related to a child or parent performing parental right. As a rule, the procedure is conducted in two hearings at the most. The first hearing is scheduled to be held within 15 days from the day of receiving charges in court, and the second instance court is obliged to make a decision within 30 days from the day of delivery of the charges (Article 204, paragraph 4 and 5 of the FL RS)
} 
one of the biggest deviations as compared to the rules of the general litigation procedure. Namely, a response to charges is a mandatory litigation action of the respondent in the general litigation procedure. After the court delivers them charges in a legally defined time period, the respondent is obliged to respond to the charges. If they do not, or they respond to the charges and the response is of certain nature that the court cannot act according to, if all the legally required conditions are fulfilled, the court will bring a verdict for omission as a measure of process sanction for a nonactive respondent who has not acted according to the court order or a respondent who has responded to the charges but has not complied with the rules concerning the mandatory contents of the very response.

What is characteristic for the procedure in litigations for protection against domestic violence is the fact that the court in the procedure is not limited by the legal suit. ${ }^{45}$ This means that the court is not limited to the suggestion of the required measure of protection against domestic violence which the prosecutor has pointed to in the charges. The court can also impose a measure of protection against domestic violence that has not been required in the charges if it estimates that imposing of this measure will lead to the best protection against domestic violence. ${ }^{46}$ On the other hand, in the judicial practice there is an opinion that it is justified to impose a protective measure in cases when domestic violence cannot be eliminated completely. ${ }^{47}$

When it comes to trial and investigative principles, in the procedure in litigations for protection against domestic violence the investigative principle is dominant, as opposed to the general litigation procedure in which the trial principle has the advantage. According to its active role, applying the investigative principle, the court can also define the facts which are not debatable between the parties. It can also individually investigate the facts that have not been introduced by any of the parties in the procedure. ${ }^{48}$

In the procedure in litigations for protection against domestic violence

\footnotetext{
${ }^{45}$ The decision of the District court in Novi Sad, Gž. 1099/2006 on 22/08/2007, Bilten sudske prakse Okružnog suda u Novom Sadu, No. 14/2008, Intermex, Beograd. Besides the required protective measures-restraining order and prohibition of access to the area of the place of living-in accordance with the opinion of the expert team of the Center for Social Work of the city of Novi Sad, in the specific case the court has also imposed the measure of protection against any further harassment. ${ }^{46}$ Article 287, paragraph 2 of the FL RS.

47 "Imposing a measure of protection against domestic violence is also justified when according to the opinion of expert institutions sexual abuse of an underage child cannot be eliminated completely" (A sentence from a verdict of the Supreme Court of Cassation Rev. 2857/10 on 09/06/2010, defined at the meeting of the Civil Department on 13/09/2010, Bilten Vrhovnog kasacionog suda, No. 1/2010, at 139).

${ }^{48}$ Article 205 of the FL RS.
} 
the public is excluded and the information from the court documents represents the official secret which all the participants in the procedure that have access to it are obliged to keep.

The verdict that is brought by the court in the procedure in litigations for protection against domestic violence has specific contents since it comprises both constitutive and condemnatory elements. The constitutive part of the verdict deprives the respondent of a certain right, introduces a change in the relationship of the parties, while the condemnatory part of the verdict orders the respondent to act according to the imposed measure of protection against domestic violence. It is mentioned in the literature that it is especially important for the condemnatory part of the disposition of the judgment to be formulated in a clear and precise manner, since this way complete certainty regarding the obligations of the performer of violence is provided and recognition of behavior opposite to the imposed measure of protection against domestic violence is alleviated. ${ }^{49}$

A complaint as a regular legal remedy can be lodged against the verdict brought in the procedure in litigations for protection against domestic violence. The lodged complaint does not have a suspensive effect, so it does not prolong the execution of the verdict of imposing a measure of protection against domestic violence. A complaint has the same effect when it comes to a verdict that prolongs a measure of protection against domestic violence.

Revision is allowed against a verdict brought in the procedure in litigations for protection against domestic violence. ${ }^{50}$

When the court reaches a verdict in the procedure in litigations for protection against domestic violence, it is obliged to deliver it immediately to the guardianship authority on the territory of which the member of the family who has been the subject of violence has a permanent or temporary residence. Also the court delivers the verdict to the guardianship authority on the territory of which the member of the family against whom a measure of protection against domestic violence has been imposed has a permanent or temporary residence. The verdict is delivered to the guardianship authority since it is obliged to keep records and documents about people who have been subjects of violence and people against whom a measure of protection against domestic violence has been imposed. ${ }^{51}$

\footnotetext{
${ }^{49}$ N. Petrušić 45 (2006).

${ }^{50}$ Article 208 of the FL RS.

${ }^{51}$ The way of keeping records and documents is defined by the minister in charge of family protection. The Rulebook on Records and Documents about people who have been subjects of domestic violence and people against whom a measure of protection against domestic violence was issued in the Republic of Serbia in 2005 ("Službeni glasnik RS" No. 56/2005). The Ministry of Labor, Employment and Social Policy has brought the Special Protocol for Acting of the Center for Social
} 


\section{CONCLUSION}

Domestic violence represents a serious social phenomenon the expansion of which is evident according to the available data on this form of behavior which is in opposition to the general social and moral norms and values. It is certain that by defining the rules according to which to act in the special litigation procedure for protection against domestic violence a significant progress has been made in recognition of negative significance of this form of behavior in the family and the need for protection of people who have been exposed to domestic violence. In detail defined domestic violence, widely specified group of people who are considered members of a family and people who have an active process legitimation for initiating a procedure in litigations for protection against domestic violence, special urgency of the procedure and modified principles on which the procedure is based, as well as a relatively wide range of protective measures that can be imposed by the court in the procedure, have doubtlessly contributed to offering high quality judicial protection to people who have been subjects of domestic violence. Although there is an adequate legal framework, there are still a relatively small number of victims of domestic violence who, for various reasons, decide to ask for protection in civil judicial proceedings.

Compared to the legal systems of the other countries in the region, where protection against domestic violence is usually offered in misdemeanor proceedings, with the possibility of realizing criminal legal protection, in the Republic of Serbia protection is offered both in criminal proceedings and according to the rules of the special litigation procedure for protection against domestic violence. The definition of domestic violence is in principle the same in all the legal systems in the region as well as in the Republic of Serbia, apart from the fact that the very definition is technically defined more in detail in certain legal systems. A group of people who are considered to be members of a family is mostly identical, with the ascertainment that in the legal system of the Republic of Serbia it is very widely defined. When it comes to protective measures, besides those defined by the law of the Republic of Serbia, in the countries in the region some other measures of protection against domestic violence are defined (for instance the obligation of psychosocial treatment; mandatory addiction treatment; work for a humanitarian organization or local community, etc.). Also in certain legal systems of the countries in the region the obligation of reporting domestic violence is explicitly defined, with the ascertainment that

Work-the guardianship authority in cases of domestic violence and violence over women in partnership relations in 2013. 
the very obligation is related to a large number of people and authorities.

A huge effort is undoubtedly needed in order to raise awareness in the society about the significance of protection against domestic violence. Verdicts which impose protective measures on performers of violence in the procedure in litigations for protection against domestic violence are of large significance. On one hand, they terminate the procedure of offering legal protection to people exposed to domestic violence, commands are imposed on the person who conducts violence and violent behavior is stopped. On the other hand, their function is also significant regarding preventive acting against domestic violence. Therefore, it is necessary to publish the issued court verdicts, so the general public could be informed about their contents and potential conductors of domestic violence be informed about possible sanctions for behavior that is not socially acceptable and which significantly affects functioning of a family and its members. 